Loenhout, J.A.F. van, Houtvast, J.L.A., Vercoulen, J.H., Akkermans, R.P., Wijkmans, C.J., Velden, K. van der, Paget, W.J. Q-fever patients suffer from impaired health status long after the acute phase of the illness: results from a 24-month cohort study. Journal of Infection: 201570(3), 237-246

\begin{tabular}{|l|l|}
$\begin{array}{l}\text { Postprint } \\
\text { Version }\end{array}$ & 1.0 \\
\hline Journal website & http://www.journalofinfection.com/article/S0163-4453(14)00325-9/abstract \\
\hline Pubmed link & $\underline{\text { http://www.ncbi.nlm.nih.gov/pubmed/?term=25452036 }}$ \\
\hline DOI & $10.1016 /$ j.jinf.2014.10.010
\end{tabular}

This is a NIVEL certified Post Print, more info at http://www.nivel.eu

\title{
Q-fever patients suffer from impaired health status long after the acute phase of the illness: Results from a 24-month cohort study
}

\author{
JoRis A.F. VAN LOENHOUT ${ }^{\mathrm{A},}$, JEANNINE L.A. HAUTVAST ${ }^{\mathrm{A},}$, JAN H. VERCOULEN ${ }^{\mathrm{B},}$, REINIER \\ P. AKKERMANS ${ }^{\mathrm{A},}$, CLEMENTINE J. WIJKMANS ${ }^{\mathrm{A}, \mathrm{C}}$, KOOS VAN DER VELDEN ${ }^{\mathrm{A}}$, W. JOHN \\ PAGET $^{\mathrm{A}, \mathrm{D}}$, \\ ${ }^{a}$ Academic Collaborative Centre AMPHI, Department of Primary and Community Care, \\ Radboud University Medical Center, The Netherlands \\ ${ }^{\mathrm{b}}$ Department of Medical Psychology, Radboud University Medical Center, The Netherlands \\ ${ }^{c}$ Department of Infectious Disease Control, Municipal Health Service Hart voor Brabant, The \\ Netherlands \\ ${ }^{d}$ Netherlands Institute for Health Services Research (NIVEL), Utrecht, The Netherlands
}

\section{SUMMARY}

Objectives: During the largest Q-fever outbreak ever reported, a cohort study was established to assess the health status of Q-fever patients over a 24-month period and to identify factors associated with health status.

Methods: Laboratory-confirmed Q-fever patients participated at six time points after onset of illness. Scores on twelve subdomains from two health status instruments were calculated for each time point to determine progression and compare to reference groups.

Results: The study included 336 Q-fever patients. There is a significant linear improvement over time in nine of the twelve health status subdomains. For example, the proportion of patients with severe fatigue improved from $73.0 \%$ at three months to $60.0 \%$ at twelve months and $37.0 \%$ at twenty-four months, but this was still high compared to a healthy reference group (2.5\%). For the three most severely affected subdomains -'Fatigue', 'General Quality of Life' and 'Role Physical'- the baseline characteristics significantly associated with a longterm reduced health status were being female, being a young adult and having pre-existing health problems.

Conclusions: Despite a significant linear improvement over time in nine of the twelve health status subdomains, more than one out of three patients still suffered from a reduced health status at 24 months. 
Loenhout, J.A.F. van, Houtvast, J.L.A., Vercoulen, J.H., Akkermans, R.P., Wijkmans, C.J., Velden, K. van der, Paget, W.J. Q-fever patients suffer from impaired health status long after the acute phase of the illness: results from a 24-month cohort study. Journal of Infection: 2015$70(3), 237-246$

\section{INTRODUCTION}

Q-fever is a zoonosis caused by the intracellular bacterium Coxiella burnetii. Approximately $40 \%$ of all persons infected with Q-fever develop symptoms such as fever, pneumonia and hepatitis. ${ }^{1 \text { and } 2}$ Several studies have shown that many patients suffer from a severely impaired health status, including persistent fatigue, after Qfever. ${ }^{3,4,5,6,7,8 \text { and } 9}$ These symptoms have been reported for as long as ten years after onset of illness, ${ }^{5}$ but there are no data on how symptoms evolve over time during the first two years after infection.

Q-fever is known to occur in small local outbreaks in Western Europe (.19 cases per 100,000 in 2011 in Europe, ranging from .00 in nine EU countries to .60 per 100,000 in Cyprus ${ }^{10}$ ), which are usually associated with livestock farming. ${ }^{1 \text { and } 11}$ Between 2007 and 2009, the number of notified cases of Q-fever increased annually in the Netherlands, a country of 17 million inhabitants, and reached a cumulative total of 4107 in 2011, making it the largest documented outbreak in the world. ${ }^{12}$ Measures taken in late 2009 to prevent the further spread of the disease led to a massive reduction in notifications from 2010 onwards (there were 81 cases in 2011). ${ }^{12}$ A study carried out in the Netherlands in 2009 found that there were high levels of severe fatigue and low levels of general quality of life 12-26 months after infection. ${ }^{8}$ In addition, the Dutch Q-fever patient organisation reported many long-term impairments (e.g. severe symptoms of fatigue, depression and unemployment). ${ }^{13}$ In order to provide prospective data on Q-fever patients, we established a cohort study to systematically asses health status progression over a 24-month period. We also identified individual characteristics associated with health status at 12 and 24 months.

\section{MATERIALS AND METHODS}

The design used was a prospective cohort study of Q-fever patients over a period of 24 months after onset of illness. The study protocol was submitted to the Medical Ethical Review Board of the region Arnhem-Nijmegen, which indicated that ethical review was not required.

The study population was patients diagnosed with Q-fever in 2010 and 2011 in the Netherlands, who were at least 18 years of age and fulfilled the Dutch notification criteria of Q-fever. ${ }^{14}$ The standard treatment for patients with a Q-fever infection used by general practitioners in the Netherlands is $2-3$ weeks of antibiotics, preferably Doxycycline (200 mg per day). ${ }^{12}$

\section{Data collection}

All Municipal Health Services in the Netherlands were asked to invite Q-fever patients who met the Dutch notification criteria to participate in the study. Patients who gave permission received an information letter and a consent form by postal mail. After receiving written consent, patients were contacted by postal mail at 3, 6, 9, 12, 18 and 24 months with a questionnaire, and patients who did not return the questionnaire received a reminder by telephone or postal mail. Patients were allowed to enter the study at 3, 6, 9 or 12 months after onset of illness. 
Loenhout, J.A.F. van, Houtvast, J.L.A., Vercoulen, J.H., Akkermans, R.P., Wijkmans, C.J., Velden, K. van der, Paget, W.J. Q-fever patients suffer from impaired health status long after the acute phase of the illness: results from a 24-month cohort study. Journal of Infection: 201570(3), 237-246

\section{Questionnaire}

The study questionnaires contained two instruments to measure health status and quality of life: the Nijmegen Clinical Screening Instrument (NCSI) ${ }^{15}$ and the Short Form 36 (SF-36). ${ }^{16}$ The NCSI was originally developed to measure health status in COPD patients and provides normative data indicating normal functioning, mild or severe problems for each subdomain. ${ }^{15}$ The NCSI and SF-36 were used simultaneously since they gather information on different domains. Only the four subdomains in the SF-36 that have been shown to be not conceptually similar to subdomains in the NCSI are presented in our study. ${ }^{17}$ The NCSI was included at 3, 12,18 and 24 months.

Information on the individual characteristics of Q-fever patients that could affect health status was also collected at the time of inclusion and consisted of sociodemographic, lifestyle and medical aspects (self-reported). Characteristics which could change over time (e.g. smoking behaviour and BMI) were included in successive questionnaires.

\section{Reference groups}

To compare the NCSI scores of the Q-fever patients, an existing reference group, consisting of healthy participants, ${ }^{15}$ was expanded to match our group of Q-fever patients for age and gender. They were asked to visit Radboud university medical center, where they completed an electronic questionnaire, including the NCSI. The lung function of the healthy reference group was tested, so that persons with an undiagnosed underlying respiratory illness that could affect their health status could be excluded. For the SF-36 scores, we compared our scores to a large general population study carried out in the US. ${ }^{18}$

\section{Data analysis}

\section{Study participation}

Differences in gender and age of the Q-fever patients were analysed between participants and non-participants. Since patients could drop out of the study at each time point, the health status scores of drop-outs and patients who continued to participate were assessed, using independent samples $t$-tests.

We assessed the health status scores of patients who participated in the cohort study from 3 months onwards and patients who entered the study at a later time point, and found there were no important differences (data not shown). We have therefore focused our analyses on the outcomes of all patients in the cohort study.

\section{Health status}

For the NCSI, the proportion of severely affected patients at three time points $(3,12$ and 24 months) was calculated. In addition, mean scores for each subdomain were calculated for each follow-up time point and compared to scores from the healthy reference group. For the SF-36, mean scores for the subdomains were calculated on a scale from 0 to $100 \%$ per patient group for each time point. The scores were compared to normative scores from the general population in a large U.S. study, on a scale from 0 to $100 \%{ }^{18}$ 
Loenhout, J.A.F. van, Houtvast, J.L.A., Vercoulen, J.H., Akkermans, R.P., Wijkmans, C.J., Velden, K. van der, Paget, W.J. Q-fever patients suffer from impaired health status long after the acute phase of the illness: results from a 24-month cohort study. Journal of Infection: 2015$70(3), 237-246$

Only Q-fever patients who reported severe fatigue and/or a severe impact on their quality of life at 12 and 18 months after onset of illness were eligible for follow-up at 18 and 24 months respectively, since we wanted to focus on the most severely affected patients and did not want to burden recovered patients with additional questionnaires. For the patients with no severe score on the subdomains 'Fatigue' and 'General Quality of Life', scores at 12 and 18 months were assumed to remain the same at 18 and 24 months respectively.

\section{Individual characteristics associated with health status}

These characteristics were assessed at 12 and 24 months, but only for the most relevant subdomains. NCSI subdomains were considered relevant if the proportion of severely affected patients on the 3-month time point was higher than $40 \% .{ }^{19}$ SF-36 subdomains were considered relevant if their score on the 3-month time point differed more than $20 \%$ with the normative score. ${ }^{19}$ Only original health status scores were used for these analyses, not scores that were extrapolated to 24 months.

\section{Statistical analysis}

Score progression on each subdomain was analysed using a generalized estimating equation (GEE) model assuming an exchangeable correlation structure, both for the NCSI as well as for the SF-36. Individual characteristics associated with health status were first identified by univariate analyses, using linear regression. Characteristics that showed statistical significance in the univariate analyses were combined in a multivariate model for each subdomain. Additionally, characteristics that were not statistically significant in the multivariate model were removed via a backward analysis. To assess multicollinearity, correlation coefficients were calculated between all characteristics, and a Spearman's Rho $\geq .80$ was considered to be too high. A $p$-value of $<.05$ was considered to be statistically significant, based on twosided tests. Data were analysed using the software SPSS for Windows (version 20).

\section{RESULTS}

\section{Participation and individual characteristics of the study population}

All but one of the 25 Municipal Health Services in the Netherlands participated in the study and a total of 376 Q-fever patients were eligible. Of these, 336 agreed to participate, giving a response of $89 \%$. Our analyses of participants and nonparticipants showed no differences in gender $(p=.867)$ and age $(p=.916)$ (data not shown).

During the course of the study, 58 patients dropped out between time points (17\%). Our analyses of the drop-outs revealed that, even though the proportion of patients who were lost to follow up is small, the patients who dropped out early scored significantly worse more often than patients who continued to participate. This was the case for twelve subdomains on different time points, compared to one subdomain for which drop-outs scored better (data not shown). A detailed outline of the number of participants at each time point and the number of drop-outs can be found in Supplementary Table 1.

The individual characteristics of all patients at baseline and of those eligible for follow-up after 12 months are listed in Table 1. 
Loenhout, J.A.F. van, Houtvast, J.L.A., Vercoulen, J.H., Akkermans, R.P., Wijkmans, C.J., Velden, K. van der, Paget, W.J. Q-fever patients suffer from impaired health status long after the acute phase of the illness: results from a 24-month cohort study. Journal of Infection: 2015$70(3), 237-246$

\section{[Table 1]}

\section{Health status}

\section{NCSI}

At the 3-month time point, the highest proportion of patients who had a severely affected score were found in the subdomains 'Fatigue' (73.0\%) and 'General Quality of Life' (42.2\%) (data not shown). At the 12-month time point, these proportions were $60.0 \%$ and $50.2 \%$ and at 24 months $37.0 \%$ and $33.7 \%$ for 'Fatigue' and 'General Quality of Life' respectively, compared to 2.5\% and 19.8\% in the healthy reference group. There was a gradual improvement over time in the mean scores of Q-fever patients on all NCSI subdomains, as visualised in Fig. 1A (a lower score indicates a better health). When the effect of time on mean subdomain scores is analysed via GEE models, there is a significant linear decline in the scores of five out of eight subdomains (Table 2). No significant linear decline was found for the subdomains 'Dyspnoea Emotions’ ( $p=.061)$, 'General Quality of Life’ $(p=.084)$ and 'Satisfaction Relations' $(p=.231)$.

\section{[FIGURE 1]}

SF-36

For the SF-36 subdomain scores, there is an improvement in the mean scores of Qfever patients over time (Fig. 1B) (a higher score indicates better health). At 24 months after onset of illness, the mean score is close to the normative score for the general population for three out of four subdomains ('Role Emotional', 'Social Functioning' and 'Bodily Pain'). When this effect is analysed using GEE models, there is a statistically significant linear increase in the scores for all four subdomains (Table 2).

\section{[TABLE 2]}

\section{Individual characteristics associated with health status}

Three subdomains were selected for the analysis at 12 and 24 months: NCSI 'Fatigue' and 'General Quality of Life', and SF-36 'Role Physical', as these were the most severely affected in patients (see above). ${ }^{19}$ In the multivariate analyses on the 12-month time point, using medication and following an additional treatment for long-lasting effects of Q-fever are significantly associated with a lower health on all three subdomains. Being female, a young adult, having pre-existing health problems, consuming no alcohol and being hospitalised in the previous three months are associated with a lower health status on one or two subdomains (Table 3). For the severely affected patients at 24 months, having pre-existing health problems is associated with a lower health status on all three subdomains; consuming no alcohol, using medication and following an additional treatment for Q-fever are associated with reduced scores on one or two subdomains (Table 4). The highest correlation between individual characteristics included in the multivariate analyses, using Spearman's Rho, was found between use of medication and pre-existing health problems $(r=.40)$, indicating no problem with multicollinearity. 
Loenhout, J.A.F. van, Houtvast, J.L.A., Vercoulen, J.H., Akkermans, R.P., Wijkmans, C.J., Velden, K. van der, Paget, W.J. Q-fever patients suffer from impaired health status long after the acute phase of the illness: results from a 24-month cohort study. Journal of Infection: 2015$70(3), 237-246$

\section{[TABLE 3] [TABLE 4]}

\section{DISCUSSION}

We present the long-term health status of Q-fever patients in the Netherlands. It is the first time that such a large prospective cohort study is performed. Our study shows that many Q-fever patients suffer from a reduced health status long after the acute phase of their illness. Despite a significant and linear improvement in nine out of twelve health status subdomains of patients between 3 and 24 months after onset of illness, patients generally had low health status scores after 24 months compared to a healthy reference group. For example, the proportion of severely affected patients for the subdomain 'Fatigue' ranges from $73.0 \%$ at 3 months to $37.0 \%$ at 24 months. We feel that it is not likely that patients exaggerate their fatigue status to participate within a disability policy, as this leads to a reduced income and is thus not beneficial for them.

Wildman et al. hypothesised that the excess fatigue that was observed in Q-fever patients in their study might be (partly) explained by psychological distress (e.g. anxiety and depression), caused by uncertainty about their illness and repeated medical contacts reinforcing perceptions of ill health. ${ }^{5}$ The NCSI subdomain 'General Quality of Life' consists of the instrument 'Beck Depression Inventory' (BDI), which provides a measure of psychological distress. ${ }^{15}$ A study by van Loenhout et al. in a group of Q-fever patients showed that Pearson's correlation between the subdomains 'General Quality of Life' and 'Fatigue' was .50, leading to an $r^{2}$ of .25. ${ }^{17}$ These results suggest that psychological distress is not an important factor in explaining the high levels of excess fatigue found in our study.

For several subdomains, there is no significant linear improvement in health status over time (Table 2). We cannot explain why 'General Quality of Life' scores at 12 months are more impaired than at 3 months, although general quality of life of people is influenced by many factors besides their illness. For the subdomains 'Satisfaction Relations' and 'Dyspnoea Emotions', we assume there is no improvement since scores on these subdomains are relatively close to scores of the healthy controls from the 3 month follow-up period onwards.

We were only able to identify a handful of studies with a prospective study design which have been used to assess the long-term health status of patients affected by an infectious disease. A study carried out in Australia looked at patients with postinfective fatigue syndrome (among whom were 42 patients infected with $C$. burnetii) in the first year after illness ${ }^{4}$ and two other studies in the U.S. and the Netherlands reviewed health status of patients with Community-Acquired Pneumonia until 90 and 540 days after onset of illness respectively. ${ }^{20}$ and 21 All three studies support our finding that Q-fever patients, as well as those with Epstein-Barr Virus, Ross River virus and Community-Acquired Pneumonia, show post-infective fatigue and recover gradually from their infection.

\section{Individual characteristics associated with health status at 12 months}

We found that women score worse on the subdomain 'Fatigue' than men, which is supported by general studies on gender and health where women are more prone to report health problems. ${ }^{22}$ and 23 The relationship between age and 'General Quality of Life' suggests that older people can accept their health problems more easily. Having 
Loenhout, J.A.F. van, Houtvast, J.L.A., Vercoulen, J.H., Akkermans, R.P., Wijkmans, C.J., Velden, K. van der, Paget, W.J. Q-fever patients suffer from impaired health status long after the acute phase of the illness: results from a 24-month cohort study. Journal of Infection: 2015$70(3), 237-246$

pre-existing health problems was associated with a lower health status on all three subdomains, which is supported by other studies (e.g. on cardiovascular illnesses, rheumatoid arthritis, diabetes). ${ }^{24,25}$ and 26 Although the proportion of patients with preexisting health problems is high (39.7\%), this figure is in line with persons with underlying conditions in the general Dutch population (46.8\%), ${ }^{27}$ and low compared to patients with Legionnaires' disease (59.5\%), even though there is no difference in long-term health status of Q-fever patients and patients with Legionnaires' disease. ${ }^{19}$ For all individual characteristics measured at 12 months, we cannot infer a causal relationship with health status, as these characteristics can change over time. Characteristics which were, as expected, associated with concurrent reduced health status, are using medication and being hospitalised. More surprising is the finding that a lower alcohol consumption is associated with a reduced health status on two subdomains. Another unexpected result is the reduced score of patients who follow an additional treatment for long-lasting effects of Q-fever. A possible explanation is that patients only seek additional treatment for Q-fever when their health status is seriously impaired.

\section{Individual characteristics associated with health status of severely affected patients at 24 months}

Since only patients with a severely affected score at 12 and 18 months on the subdomains ‘Fatigue' and 'General Quality of Life' were eligible for subsequent follow-up, the group of patients at 24 months is different to the 12-month group (e.g. the higher proportion of women and persons with pre-existing health problems, see Table 1). Having pre-existing health problems at baseline is the only characteristic which is associated with a reduced score on all three health status subdomains and seems to be the most influential in affecting health status in the group of patients with a severely affected long-term health status. ${ }^{24,25 \text { and } 26}$ Individual characteristics measured at 24 months associated with a reduced health status on at least one subdomain are, consistent with 12 months, not consuming alcohol, using medication and following an additional treatment for Q-fever. Having pre-existing health problems and these three characteristics are all negatively associated with health status of the most severe patients.

\section{Limitations}

One limitation of our study is the reference groups that we used to interpret our findings. For the SF-36 subdomains, we compared the mean scores of Q-fever patients to the mean scores of the general population in a large U.S. study. For the NCSI, only normative data from a healthy reference group were available. In addition, both groups were not serologically tested for Q-fever, so it is possible that persons are included who previously underwent a Q-fever infection (more likely for the Dutch than for the U.S. reference group). Since the reference group for the NCSI consists of healthy controls, they are by definition more healthy than the general population, which leads to an overestimation of health status. Studies on fatigue in

the general population imply that baseline fatigue levels are already quite high, ${ }^{28}$ and 29 and this means the high proportion of patients who are severely affected on the subdomain 'Fatigue' might also include fatigue due to other reasons than the infectious illness under study. 
Loenhout, J.A.F. van, Houtvast, J.L.A., Vercoulen, J.H., Akkermans, R.P., Wijkmans, C.J., Velden, K. van der, Paget, W.J. Q-fever patients suffer from impaired health status long after the acute phase of the illness: results from a 24-month cohort study. Journal of Infection: 201570(3), 237-246

Due to the fact that all patients were included through Municipal Health Services, our study included only patients who fitted the Dutch case definition for acute Qfever. A population-based surveillance study would provide more insight into the long-term health problems of all persons with a Q-fever infection and such a study ( $n$ $=2163$ ) is currently ongoing. ${ }^{30}$

The results of our study might be an underrepresentation of the actual patient scores, for two reasons. First, the small number of patients who dropped out of the study early generally had a lower health status compared to patients who continued to participate. Second, patients who were not severely affected on the subdomains 'Fatigue' and 'General Quality of Life' at the 12- or 18-month time points were not eligible for further participation. Their scores were extrapolated to subsequent time points, although in reality health status of some patients could have decreased again. Finally, our results do not provide insight into the reasons why some patients have a severely affected long-term health status while others have not, as this is a population-based analysis.

\section{CONCLUSION}

This large prospective study showed that there is a significant linear improvement over time in nine of the twelve health status subdomains from 3 to 24 months after onset of illness. However, more than one out of three patients still had reduced health status scores at 24 months (37\% suffered from severe fatigue). This information can be used to present the expected disease progression to newly infected Q-fever patients. Our analyses also helped identify baseline characteristics associated with a reduced long-term health status, namely being female, being a young adult, and suffering from pre-existing health problems, which can be used by health care workers (e.g. General Practitioners) to identify patients with a higher risk for a reduced health status. These findings show there is a substantial long-term impact of Q-fever, and they are important for healthcare workers around the world who are confronted with a Q-fever outbreak in the community. Although there is no standard treatment for Q-fever patients with a long-term impaired health status, a clinical trial is currently being carried out in the Netherlands that could provide more insight into effective therapies for these patients. ${ }^{31}$

\section{FUNDING}

This work was supported by ZonMw, the Netherlands organization for Health Research and Development [project number 50-50405-98-131]. The funding source had no role in the study design, data collection, analysis, and interpretation of data, writing of the report, and in the decision to submit the paper for publication.

\section{ACKNOWLEDGEMENTS}

We thank G. Morroy, W. van der Hoek, F. Dijkstra, P. Schneeberger, A. Olde Loohuis, R. Daemen and L. Wielders for their contributions in developing the study protocol and advice during the study performance, and J. van den Heuvel and F. de Leeuw for collecting data. 
Loenhout, J.A.F. van, Houtvast, J.L.A., Vercoulen, J.H., Akkermans, R.P., Wijkmans, C.J., Velden, K. van der, Paget, W.J. Q-fever patients suffer from impaired health status long after the acute phase of the illness: results from a 24-month cohort study. Journal of Infection: 2015$70(3), 237-246$

\section{APPENDIX A. SUPPLEMENTARY DATA}

\section{REFERENCES}

1 G. Dupuis, J. Petite, O. Peter, M. Vouilloz An important outbreak of human Q fever in a Swiss Alpine valley Int J Epidemiol, 16 (2) (1987), pp. 282-287 Epub 1987/06/01

2 D. Raoult, T. Marrie, J. Mege Natural history and pathophysiology of Q fever Lancet Infect Dis, 5 (4) (2005), pp. 219-226 Epub 2005/03/29

3 J.G. Ayres, N. Flint, E.G. Smith, W.S. Tunnicliffe, T.J. Fletcher, K. Hammond, et al. Postinfection fatigue syndrome following Q fever QJM, 91 (2) (1998), pp. 105-123 Epub 1998/05/14

4 I. Hickie, T. Davenport, D. Wakefield, U. Vollmer-Conna, B. Cameron, S.D. Vernon, et al. Post-infective and chronic fatigue syndromes precipitated by viral and non-viral pathogens: prospective cohort study BMJ, 333 (7568) (2006), p. 575 Epub 2006/09/05

5 M.J. Wildman, E.G. Smith, J. Groves, J.M. Beattie, E.O. Caul, J.G. Ayres Chronic fatigue following infection by Coxiella burnetii (Q fever): ten-year follow-up of the 1989 UK outbreak cohort QJM, 95 (8) (2002), pp. 527-538 Epub 2002/07/30

6 T.F. Hatchette, M. Hayes, H. Merry, W.F. Schlech, T.J. Marrie The effect of C. burnetii infection on the quality of life of patients following an outbreak of $Q$ fever Epidemiol Infect, 130 (3) (2003), pp. 491-495 Epub 2003/06/27

7 G.J. Limonard, J.B. Peters, M.H. Nabuurs-Franssen, G. Weers-Pothoff, R. Besselink, C.A. Groot, et al. Detailed analysis of health status of Q fever patients 1 year after the first Dutch outbreak: a case-control study QJM, 103 (12) (2010), pp. 953-958 Epub 2010/08/31

8 G. Morroy, J.B. Peters, M. van Nieuwenhof, H.H. Bor, J.L. Hautvast, W. van der Hoek, et al. The health status of Q-fever patients after long-term follow-up BMC Infect Dis, 11 (2011), p. 97 Epub 2011/04/20

9 B.P. Marmion, M. Shannon, I. Maddocks, P. Storm, I. Penttila Protracted debility and fatigue after acute Q fever Lancet, 347 (9006) (1996), pp. 977-978 Epub 1996/04/06

10 Annual Epidemiological Report European Centre for disease Prevention and control, 2013 (2013)

11 A. Gilsdorf, C. Kroh, S. Grimm, E. Jensen, C. Wagner-Wiening, K. Alpers Large Q fever outbreak due to sheep farming near residential areas, Germany, 2005 Epidemiol Infect, 136 (8) (2008), pp. 1084-1087 Epub 2007/09/26

12 RIVM. Rijksinstituut voor Volksgezondheid en Milieu: ziekten en aandoeningen (National Institute for Public Health and the Environment: diseases and infections). Available from: http://rivm.nl/Onderwerpen/Ziekten_Aandoeningen.

13 Q-uestion, Stichting voor mensen met Q-koorts (Foundation for persons with Q-fever). Available from: http://stichtingquestion.nl/.

14 F. Dijkstra, W. van der Hoek, N. Wijers, B. Schimmer, A. Rietveld, C.J. Wijkmans, et al. The 2007-2010 Q fever epidemic in the Netherlands: characteristics of notified acute Q fever patients and the association with dairy goat farming FEMS Immunol Med Microbiol, 64 (1) (2012), pp. 3-12 Epub 2011/11/10

15 J.B. Peters, L. Daudey, Y.F. Heijdra, J. Molema, P.N. Dekhuijzen, J.H. Vercoulen Development of a battery of instruments for detailed measurement of health status in patients with COPD in routine care: the Nijmegen Clinical Screening Instrument Qual Life Res, 18 (7) (2009), pp. 901-912 Epub 2009/06/23

16 J.E. Ware Jr., M. Kosinski, M.S. Bayliss, C.A. McHorney, W.H. Rogers, A. Raczek Comparison of methods for the scoring and statistical analysis of SF-36 health profile and summary measures: summary of results from the Medical Outcomes Study Med Care, 33 (4 Suppl.) (1995), pp. AS264-AS279 Epub 1995/04/01

17 J.A. van Loenhout, W.J. Paget, G.W. Sandker, J.L. Hautvast, K. van der Velden, J.H. Vercoulen Assessing health status and quality of life of Q-fever patients: the Nijmegen Clinical Screening Instrument versus the Short Form 36 Health Qual Life Outcomes, 11 (1) (2013), p. 112 Epub 2013/07/06

18 J.E. Ware Jr. SF-36 health survey update Spine, 25 (24) (2000), pp. 3130-3139 Epub 2000/12/22 
Loenhout, J.A.F. van, Houtvast, J.L.A., Vercoulen, J.H., Akkermans, R.P., Wijkmans, C.J., Velden, K. van der, Paget, W.J. Q-fever patients suffer from impaired health status long after the acute phase of the illness: results from a 24-month cohort study. Journal of Infection: 201570(3), 237-246

19 J.A. van Loenhout, H.H. van Tiel, J. van den Heuvel, J.H. Vercoulen, H. Bor, K. van der Velden, et al. Serious long-term health consequences of Q-fever and Legionnaires' disease J Infect, 68 (6) (2014), pp. 527-533 Epub 2014/01/29

20 J.P. Metlay, M.J. Fine, R. Schulz, T.J. Marrie, C.M. Coley, W.N. Kapoor, et al. Measuring symptomatic and functional recovery in patients with community-acquired pneumonia $\mathrm{J}$ Gen Intern Med, 12 (7) (1997), pp. 423-430 Epub 1997/07/01

21 R. El Moussaoui, B.C. Opmeer, C.A. de Borgie, P. Nieuwkerk, P.M. Bossuyt, P. Speelman, et al. Long-term symptom recovery and health-related quality of life in patients with mild-to-moderate-severe community-acquired pneumonia Chest, 130 (4) (2006), pp. 1165-1172 Epub 2006/10/13

22 E. Haavio-Mannila Inequalities in health and gender Soc Sci Med, 22 (2) (1986), pp. 141149 Epub 1986/01/01

23 K.H. Ladwig, B. Marten-Mittag, B. Formanek, G. Dammann Gender differences of symptom reporting and medical health care utilization in the German population Eur $\mathrm{J}$ Epidemiol, 16 (6) (2000), pp. 511-518 Epub 2000/10/26

24 J. Juenger, D. Schellberg, S. Kraemer, A. Haunstetter, C. Zugck, W. Herzog, et al. Health related quality of life in patients with congestive heart failure: comparison with other chronic diseases and relation to functional variables Heart, 87 (3) (2002), pp. 235-241 Epub 2002/02/16

25 Y. Garip, F. Eser, L.A. Aktekin, H. Bodur Fatigue in rheumatoid arthritis: association with severity of pain, disease activity and functional status Acta Reumatol Port, 36 (4) (2011), pp. 364-369 Epub 2012/04/05

26 R.E. Glasgow, L. Ruggiero, E.G. Eakin, J. Dryfoos, L. Chobanian Quality of life and associated characteristics in a large national sample of adults with diabetes Diabetes Care, 20 (4) (1997), pp. 562-567 Epub 1997/04/01

27 CBS. Statistics Netherlands. Available from: http://www.cbs.nl.

28 M. van't Leven, G.A. Zielhuis, J.W. van der Meer, A.L. Verbeek, G. Bleijenberg Fatigue and chronic fatigue syndrome-like complaints in the general population Eur J Public Health, 20 (3) (2010), pp. 251-257 Epub 2009/08/20

29 R.D. Kocalevent, A. Hinz, E. Brahler, B.F. Klapp Determinants of fatigue and stress BMC Res Notes, 4 (2011), p. 238 Epub 2011/07/22

30 GGD Hart voor Brabant: first results Q Herpen II study. [8 July 2014]; Available from: http://www.ggdhvb.nl/nl-nl/Actueel/Nieuws/2014/05/Eerste-resultaten-Q-Herpen-IIonderzoek.

31 S.P. Keijmel, C.E. Delsing, T. Sprong, G. Bleijenberg, J.W. van der Meer, H. Knoop, et al. The Qure study: Q fever fatigue syndrome-response to treatment; a randomized placebocontrolled trial BMC Infect Dis, 13 (2013), p. 157 Epub 2013/03/30 
Loenhout, J.A.F. van, Houtvast, J.L.A., Vercoulen, J.H., Akkermans, R.P., Wijkmans, C.J., Velden, K. van der, Paget, W.J. Q-fever patients suffer from impaired health status long after the acute phase of the illness: results from a 24-month cohort study. Journal of Infection: 201570(3), 237-246

\section{TABLES}

Table 1. Individual characteristics of Q-fever patients at time of inclusion in the study and patients who were eligible for follow-up after 12 months after onset of illness, for which associations with health status were analysed.

\begin{tabular}{|c|c|c|c|c|}
\hline Variable & Inclusion $^{\mathrm{a}}$ & $\begin{array}{c}\text { Out of } \\
\text { (N) }\end{array}$ & \begin{tabular}{|c} 
Eligible after 12 \\
Months $^{c}$
\end{tabular} & $\begin{array}{c}\text { Out of }^{\mathrm{d}} \\
(\mathrm{N})\end{array}$ \\
\hline Male sex \% & 54.8 & 336 & 50.0 & 216 \\
\hline Age $^{e}$ (years) Mean $( \pm S D)$ & \begin{tabular}{|l|}
48.5 \\
$(13.9)$
\end{tabular} & ||336 & $48.0(14.0)$ & ||216 \\
\hline Educational level \% & & 335 & & 216 \\
\hline Low & 41.2 & & 40.7 & \\
\hline Middle & 30.4 & & 32.4 & \\
\hline High & 28.4 & & 26.9 & \\
\hline Dutch Nationality ${ }^{\mathrm{f}} \%$ & 98.5 & 336 & 98.6 & 216 \\
\hline \begin{tabular}{|l|}
$\begin{array}{l}\text { Pre-existing health } \\
\text { problems, }\end{array}$ \\
\end{tabular} & 39.7 & ||335 & 46.8 & ||216 \\
\hline $\begin{array}{l}\text { Diagnosis during Q-fever } \\
\text { episode }{ }^{\mathrm{h}, \mathrm{i}} \%\end{array}$ & & |335 & & 216 \\
\hline Pneumonia & 48.4 & & 52.8 & \\
\hline Meningitis & .0 & & .0 & \\
\hline Endocarditis & .9 & & .9 & \\
\hline Hepatitis & 5.7 & & 6.5 & \\
\hline $\begin{array}{l}\text { Pregnancy complications (\% } \\
\text { of women) }\end{array}$ & .7 & ||152 & .9 & $\mid 108$ \\
\hline Body mass index ${ }^{j} \%$ & & 334 & & 215 \\
\hline \begin{tabular}{|l|} 
Underweight \\
\end{tabular} & .6 & & .9 & \\
\hline Normal weight & 40.7 & & 39.5 & \\
\hline Moderately overweight & 46.1 & & 40.5 & \\
\hline Seriously overweight & 12.6 & & 19.1 & \\
\hline Smoking behaviour \% & & 336 & & 216 \\
\hline Current & 30.4 & & 30.1 & \\
\hline Former & 37.5 & & 38.4 & \\
\hline Never & 32.1 & & 31.5 & \\
\hline \begin{tabular}{|l} 
Alcohol consumption \\
(beverages/week) \%
\end{tabular} & & |336 & & 216 \\
\hline 0 & 34.8 & & 36.1 & \\
\hline $1-6$ & 39.6 & & 43.1 & \\
\hline$\geq 7$ & 25.6 & & 20.8 & \\
\hline
\end{tabular}


Loenhout, J.A.F. van, Houtvast, J.L.A., Vercoulen, J.H., Akkermans, R.P., Wijkmans, C.J., Velden, K. van der, Paget, W.J. Q-fever patients suffer from impaired health status long after the acute phase of the illness: results from a 24-month cohort study. Journal of Infection: 2015$70(3), 237-246$

\begin{tabular}{|c|c|c|c|c|}
\hline Variable & Inclusion $^{\mathrm{a}}$ & $\begin{array}{c}\text { Out of } \\
\text { (N) }\end{array}$ & 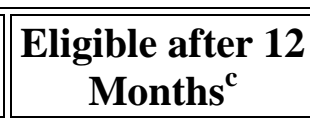 & $\begin{array}{c}\text { Out of }^{\mathrm{d}} \\
(\mathrm{N})\end{array}$ \\
\hline Use of medication $^{\mathrm{k}} \%$ & 46.4 & 336 & 56.9 & 216 \\
\hline Hospitalisation $\%$ & 11.0 & 310 & 13.9 & 216 \\
\hline $\begin{array}{l}\text { Additional treatment for Q- } \\
\text { fever }^{\mathrm{m}, \mathrm{n}}(\mathrm{N})\end{array}$ & & |305 & & 216 \\
\hline $\begin{array}{l}\text { Cognitive behavioural } \\
\text { therapy }\end{array}$ & $\mid 14$ & & 4 & \\
\hline Graded exercise therapy & 19 & & 11 & \\
\hline $\begin{array}{l}\text { Additional treatment with } \\
\text { antibiotics }\end{array}$ & ||38 & & 26 & \\
\hline Participation in Qure study & 14 & & 0 & \\
\hline Other & 29 & & 18 & \\
\hline Pregnancy ${ }^{\mathrm{t}, \mathrm{m}}(\mathrm{N})$ & 11 & 152 & 4 & 108 \\
\hline Working $^{0} \%$ & 74.0 & 335 & 76.3 & 215 \\
\hline
\end{tabular}

a) Inclusion in the study was possible at time point 3, 6, 9 or 12 .

b) The total number of participants included in the study was 336, the total number of women 152. Due to some missing data, this value is smaller for some characteristics. Hospitalisation and additional treatment were included from the 12-month time point onwards, with a maximum $\mathrm{N}$ of 310.

c) Patients were eligible for follow-up at 12 months after onset of illness if they had a severe score on the subdomains 'Fatigue' and/or 'General Quality of Life'.

d) The total number of patients eligible for follow-up after 12 months was 216, the total number of women 108. The Body Mass Index of one patient was missing.

e) Age during onset of illness.

f) Associations between nationality and pregnancy on one side and health status on the other side were not analysed, due to the small numbers of observations.

g) Pre-existing health problems consists of a large number of conditions, including but not limited to cardiovascular, pulmonary, renal, neurological conditions, diabetes, depression.

h) Pre-existing health problems and Diagnosis during Q-fever episode are self-reported.

i) In the analyses, a patient is considered as having a severe illness during the acute phase of Q-fever if he/she suffered from pneumonia, meningitis, endocarditis, hepatitis or pregnancy complications.

j) Body Mass Index was analysed as a continuous variable.

k) Only patients with one or more prescribed medicines were categorised as using medication. Patients who only used self-prescribed medication and/or homeopathic remedies were not.

l) Hospitalisation was included from the 12-month time point onwards. This variable describes hospitalisation between 9 and 12 months after onset of illness.

m) The values given for Additional treatment for Q-fever and Pregnancy are the number of patients during the course of the study for the inclusion column, and the number of 
Loenhout, J.A.F. van, Houtvast, J.L.A., Vercoulen, J.H., Akkermans, R.P., Wijkmans, C.J., Velden, K. van der, Paget, W.J. Q-fever patients suffer from impaired health status long after the acute phase of the illness: results from a 24-month cohort study. Journal of Infection: 2015$70(3), 237-246$

patients at 12 months after onset of illness for the column presenting information of eligible patients.

n) Additional treatment for long-lasting health effects of Q-fever (e.g. fatigue). Treatments for Q-fever that are considered regular are Cognitive Behavioural Therapy, Graded Exercise Therapy, additional treatment with antibiotics or participation in the Qure study. ${ }^{31}$ Other treatments are considered non-regular.

o) Working is defined as patients who worked before their Q-fever infection.

Table 2. B-values and significance levels for disease progression of Q-fever patients over time (3 to 24 months) for each subdomain, using a GEE ( $n=336$ patients).

\begin{tabular}{|c|c|c|c|c|}
\hline & Subdomain & $b$-value ${ }^{\text {a }}(\mathrm{CI})$ & $\begin{array}{c}p \text { - } \\
\text { value }\end{array}$ & $N^{b}$ \\
\hline \multirow{8}{*}{$\mathrm{NCSI}^{\mathrm{C}}$} & $\begin{array}{l}\text { Subjective pulmonary } \\
\text { symptoms }\end{array}$ & $-.60(-.98$ to -.22$)$ & .002 & 969 \\
\hline & Dyspnoea emotions & $--.25(-.52$ to .01$)$ & .061 & 964 \\
\hline & Fatigue & $\begin{array}{l}-4.82(-6.02 \text { to } \\
-3.63)\end{array}$ & $<.001$ & 957 \\
\hline & Behavioural impairment & $-1.02(-1.88$ to -.16$)$ & .020 & 970 \\
\hline & Subjective impairment & $-.79(-1.17$ to -.41$)$ & $<<.001$ & 966 \\
\hline & General quality of life & $-8.98(-2.09$ to .13$)$ & .084 & 968 \\
\hline & Health-related quality of life & $-.44(-.58$ to -.30$)$ & $<.001$ & 970 \\
\hline & Satisfaction relations & $-.08(-.22$ to .05$)$ & .231 & 963 \\
\hline \multirow{4}{*}{ SF-36 } & Role physical & 14.57 (11.58 to 17.57$)$ & $<.001$ & 1492 \\
\hline & Bodily pain & 4.54 (3.02 to 6.06$)$ & $<.001$ & 1495 \\
\hline & Social functioning & 5.71 (4.09 to 7.33$)$ & $<.001$ & 1491 \\
\hline & Role emotional & 4.73 (1.73 to 7.73$)$ & .002 & 1488 \\
\hline
\end{tabular}

a) The unit of the listed b-values is the score difference per year, ranging from 3 to 24 months after onset of illness.

b) $\quad \mathrm{N}$ is the total number of measurements on which the scores are based. c) For the NCSI subdomains, a lower score indicates a better health. For the SF-36 subdomains, a higher score indicates a better health. 
Table 3. B-values and significance levels for the relation between individual characteristics and health status of Q-fever patients for selected subdomains on the 12-month time point using multivariate analyses.

\begin{tabular}{|c|c|c|c|c|c|c|}
\hline \multirow{3}{*}{$\begin{array}{c}\text { Independent } \\
\text { variable }^{\mathrm{a}}\end{array}$} & \multicolumn{6}{|c|}{ Dependent variables $^{b}$} \\
\hline & \multicolumn{2}{|c|}{ Fatigue $^{c}$} & \multicolumn{2}{|c|}{$\begin{array}{c}\text { General Quality } \\
\text { of Life }^{d}\end{array}$} & \multicolumn{2}{|c|}{ Role physical $^{\mathrm{e}}$} \\
\hline & $\begin{array}{c}b \text {-value } \\
\text { (CI) }\end{array}$ & $\begin{array}{c}p- \\
\text { value }\end{array}$ & $\begin{array}{c}b \text {-value } \\
\text { (CI) }\end{array}$ & $\begin{array}{c}p- \\
\text { value }\end{array}$ & $\begin{array}{c}b \text {-value } \\
\text { (CI) }\end{array}$ & $\begin{array}{c}p- \\
\text { value }\end{array}$ \\
\hline Intercept & \begin{tabular}{|l}
41.57 \\
$(38.31$ to \\
$44.83)$ \\
\end{tabular} & $<.001$ & \begin{tabular}{|l}
29.85 \\
$(23.19$ to \\
$36.51)$ \\
\end{tabular} & $<.001$ & $\mid \begin{array}{l}45.64(36.69 \\
\text { to } 54.60)\end{array}$ & $<.001$ \\
\hline \multicolumn{7}{|c|}{ Variables measured at baseline } \\
\hline \multicolumn{7}{|c|}{ Gender } \\
\hline Male & $\begin{array}{l}-4.21 \\
(-7.58 \text { to } \\
-.85) \\
\end{array}$ & .014 & & & & \\
\hline Female & Ref. & & & & & \\
\hline Age & & & $\begin{array}{l}-.17(-.28 \\
\text { to }-.06)\end{array}$ & .003 & & \\
\hline \multicolumn{7}{|c|}{ Pre-existing health problems } \\
\hline Yes & $\begin{array}{l}4.45(.79 \\
\text { to } 8.10)\end{array}$ & .017 & $\begin{array}{l}3.99(.70 \text { to } \\
7.27)\end{array}$ & .018 & & \\
\hline No & Ref. & & Ref. & & & \\
\hline \multicolumn{7}{|c|}{ Variables measured at 12 months } \\
\hline \begin{tabular}{|l} 
Alcohol \\
consumption \\
(week)
\end{tabular} & & & & .003 & & .013 \\
\hline$\geq 7$ & & & \begin{tabular}{|l}
-6.73 \\
$(-10.74$ to \\
$-2.71)$ \\
\end{tabular} & .001 & $\mid \begin{array}{l}18.61(6.14 \\
\text { to } 31.07)\end{array}$ & .004 \\
\hline $1-6$ & & & \begin{tabular}{|l}
-1.55 \\
$(-4.93$ to \\
$1.83)$ \\
\end{tabular} & .367 & \begin{tabular}{|l}
$9.73(-.86$ \\
to 20.33$)$
\end{tabular} & .072 \\
\hline 0 & & & Ref. & & Ref. & \\
\hline \multicolumn{7}{|l|}{ Use of medication } \\
\hline Yes & $\begin{array}{l}4.49(.96 \\
\text { to } 8.03)\end{array}$ & .013 & (3.40 $(.10$ to & .043 & \begin{tabular}{|l}
-19.30 \\
$(-28.62$ to \\
$-9.99)$ \\
\end{tabular} & $<.001$ \\
\hline No & Ref. & & Ref. & & & \\
\hline
\end{tabular}


Loenhout, J.A.F. van, Houtvast, J.L.A., Vercoulen, J.H., Akkermans, R.P., Wijkmans, C.J., Velden, K. van der, Paget, W.J. Q-fever patients suffer from impaired health status long after the acute phase of the illness: results from a 24-month cohort study. Journal of Infection: 2015$70(3), 237-246$

\begin{tabular}{|c|c|c|c|c|c|c|}
\hline \multirow{3}{*}{$\begin{array}{c}\text { Independent } \\
\text { variable }^{\mathrm{a}}\end{array}$} & \multicolumn{6}{|c|}{ Dependent variables $^{\mathrm{b}}$} \\
\hline & \multicolumn{2}{|c|}{ Fatigue $^{c}$} & \multicolumn{2}{|c|}{$\begin{array}{c}\text { General Quality } \\
\text { of Life }^{d}\end{array}$} & \multicolumn{2}{|c|}{ Role physical $^{\mathrm{e}}$} \\
\hline & $\begin{array}{c}b \text {-value } \\
\text { (CI) }\end{array}$ & \begin{tabular}{|c|}
$p-$ \\
value
\end{tabular} & $\begin{array}{c}b \text {-value } \\
\text { (CI) }\end{array}$ & \begin{tabular}{|c|}
$p-$ \\
value
\end{tabular} & $\begin{array}{c}b \text {-value } \\
\text { (CI) }\end{array}$ & $\begin{array}{c}p \text { - } \\
\text { value }\end{array}$ \\
\hline \multicolumn{7}{|l|}{ Hospitalisation $^{\mathrm{f}}$} \\
\hline Yes & & & $\begin{array}{l}5.23(.49 \text { to } \\
9.97)\end{array}$ & .031 & $\begin{array}{l}-15.26 \\
(-30.04 \text { to } \\
-.49)\end{array}$ & .043 \\
\hline No & & & Ref. & & Ref. & \\
\hline $\begin{array}{l}\text { Additional } \\
\text { treatment for Q- } \\
\text { fever }^{\mathrm{g}}\end{array}$ & & .008 & & .018 & & $<.001$ \\
\hline Yes & $\begin{array}{l}7.38(2.36 \\
\text { to } 12.40)\end{array}$ & .004 & $\begin{array}{l}5.72(1.17 \\
\text { to } 10.27)\end{array}$ & .014 & $\begin{array}{l}-25.02 \\
(-39.06 \text { to } \\
-10.99) \\
\end{array}$ & .001 \\
\hline $\begin{array}{l}\text { Non-regular } \\
\text { treatment }\end{array}$ & \begin{tabular}{|l}
6.15 \\
$(-2.07$ to \\
$14.36)$ \\
\end{tabular} & .142 & $\begin{array}{l}5.71(-1.51 \\
\text { to } 12.93)\end{array}$ & .121 & \begin{tabular}{|l}
-27.66 \\
$(-50.37$ to \\
$-4.95)$ \\
\end{tabular} & .017 \\
\hline No & Ref. & & Ref. & & Ref. & \\
\hline
\end{tabular}

a) All variables were tested but only the significant variables were included in the final multivariate models. Additional characteristics that were tested but not significant in either of the models are Educational level, Diagnosis during the acute Q-fever episode, BMI and Smoking behaviour, since they were not significantly associated with the selected subdomains in the multivariate analyses.

b) A lower score on the NCSI subdomains 'Fatigue' and 'General Quality of Life' indicates better health. A higher score on the SF-36 subdomain 'Role Physical' indicates better health.

c) For the subdomain 'Fatigue', also the characteristics Alcohol consumption and Hospitalisation were statistically significant in the univariate analysis. In the multivariate model, they were removed via a backward analysis.

d) For the subdomain 'General Quality of Life', also the characteristic Gender was statistically significant in the univariate analysis. In the multivariate model, it was removed via a backward analysis.

e) For the subdomain 'Role Physical', also the characteristics Gender, Pre-existing health problems and Diagnosis during the acute Q-fever episode were statistically significant in the univariate analysis. In the multivariate model, they were removed via a backward analysis.

f) Hospitalisation comprises the period between 9 and 12 months after onset of illness. 
Loenhout, J.A.F. van, Houtvast, J.L.A., Vercoulen, J.H., Akkermans, R.P., Wijkmans, C.J., Velden, K. van der, Paget, W.J. Q-fever patients suffer from impaired health status long after the acute phase of the illness: results from a 24-month cohort study. Journal of Infection: 201570(3), 237-246

g) Additional treatment for long-lasting health effects of Q-fever (e.g. fatigue). Treatments for Q-fever that are considered regular are Cognitive Behavioural Therapy, Graded Exercise Therapy, additional treatment with antibiotics or participation in the Qure study. ${ }^{31}$ Other treatments are considered non-regular.

Table 4. B-values and significance levels for the relation between individual characteristics and health status of Q-fever patients with a severely affected health status for selected subdomains on the 24-month time point using multivariate analyses.

\begin{tabular}{|c|c|c|c|c|c|c|}
\hline \multirow{3}{*}{$\begin{array}{c}\text { Independent } \\
\text { variable }^{\mathrm{a}}\end{array}$} & \multicolumn{6}{|c|}{ "Dependent variables ${ }^{b}$} \\
\hline & \multicolumn{2}{|c|}{ Fatigue $^{c}$} & \multicolumn{2}{|c|}{$\begin{array}{c}\text { General Quality } \\
\text { of Life }^{d}\end{array}$} & \multicolumn{2}{|c|}{ Role Physical $^{\mathrm{e}}$} \\
\hline & $\begin{array}{c}b \text {-value } \\
\text { (CI) }\end{array}$ & \begin{tabular}{|c|}
$p-$ \\
value
\end{tabular} & $\begin{array}{c}b \text {-value } \\
\text { (CI) }\end{array}$ & \begin{tabular}{|c|}
$p-$ \\
value
\end{tabular} & b-value (CI) & $\begin{array}{c}p \text { - } \\
\text { value }\end{array}$ \\
\hline Intercept & \begin{tabular}{|l}
42.18 \\
$(39.31$ to \\
$45.04)$
\end{tabular} & $\mid<.001$ & $\begin{array}{l}25.55 \\
(22.21 \text { to } \\
28.88)\end{array}$ & $<.001$ & $\mid \begin{array}{l}30.76(17.83 \\
\text { to } 43.69)\end{array}$ & $<.001$ \\
\hline \multicolumn{7}{|c|}{ Variables measured at baseline } \\
\hline \multicolumn{7}{|c|}{ Pre-existing health problems } \\
\hline Yes & $\begin{array}{l}7.41(3.65 \\
\text { to } 11.17)\end{array}$ & $\mid<.001$ & $\begin{array}{l}5.47(.44 \\
\text { to } 10.50)\end{array}$ & .033 & \begin{tabular}{|l|}
-18.45 \\
$(-31.53$ to \\
$-5.37)$ \\
\end{tabular} & .006 \\
\hline No & Ref. & & Ref. & & Ref. & \\
\hline \multicolumn{7}{|c|}{ Variables measured at 24 months } \\
\hline $\begin{array}{l}\begin{array}{l}\text { Alcohol } \\
\text { consumption } \\
\text { (week) }\end{array} \\
\end{array}$ & & & & & & .004 \\
\hline$\geq 7$ & & & & & \begin{tabular}{|l}
$21.24(4.14$ \\
to 38.33$)$
\end{tabular} & .015 \\
\hline $1-6$ & & & & & \begin{tabular}{|l}
$24.27(9.08$ \\
to 39.46$)$
\end{tabular} & .002 \\
\hline 0 & & & & & Ref. & \\
\hline \multicolumn{7}{|l|}{ Use of medication } \\
\hline Yes & & & $\begin{array}{l}6.48(1.36 \\
\text { to } 11.60)\end{array}$ & .013 & & \\
\hline No & & & Ref. & & & \\
\hline $\begin{array}{l}\begin{array}{l}\text { Additional } \\
\text { treatment for Q- }^{\text {f }} \\
\text { fever }^{\mathrm{f}}\end{array} \\
\end{array}$ & & .018 & & & & .013 \\
\hline Yes & $6.68(1.78$ & .008 & & & -26.27 & .003 \\
\hline
\end{tabular}


Loenhout, J.A.F. van, Houtvast, J.L.A., Vercoulen, J.H., Akkermans, R.P., Wijkmans, C.J., Velden, K. van der, Paget, W.J. Q-fever patients suffer from impaired health status long after the acute phase of the illness: results from a 24-month cohort study. Journal of Infection: 201570(3), 237-246

\begin{tabular}{|c|c|c|c|c|c|c|}
\hline \multirow{3}{*}{$\begin{array}{c}\text { Independent } \\
\text { variable }^{\mathrm{a}}\end{array}$} & \multicolumn{6}{|c|}{ Dependent variables ${ }^{b}$} \\
\hline & \multicolumn{2}{|c|}{ Fatigue $^{c}$} & \multicolumn{2}{|c|}{$\begin{array}{c}\text { General Quality } \\
\text { of Life }^{\mathrm{d}}\end{array}$} & \multicolumn{2}{|c|}{ Role Physical $^{\mathrm{e}}$} \\
\hline & $\begin{array}{c}b \text {-value } \\
\text { (CI) }\end{array}$ & \begin{tabular}{|c|}
$p-$ \\
value
\end{tabular} & $\begin{array}{c}b \text {-value } \\
\text { (CI) }\end{array}$ & $\begin{array}{c}p- \\
\text { value }\end{array}$ & $b$-value (CI) & $\begin{array}{c}p \text { - } \\
\text { value }\end{array}$ \\
\hline & to 11.57 ) & & & & $\begin{array}{l}(-43.63 \text { to } \\
-8.91)\end{array}$ & \\
\hline $\begin{array}{l}\text { Non-regular } \\
\text { treatment }\end{array}$ & \begin{tabular}{|l}
5.63 \\
$(-3.26$ to \\
$14.53)$
\end{tabular} & .213 & & & \begin{tabular}{|l}
-7.67 \\
$(-38.78$ to \\
$23.44)$ \\
\end{tabular} & .627 \\
\hline No & Ref. & & & & Ref. & \\
\hline
\end{tabular}

a) All variables were tested but only the significant variables were included in the final multivariate models. Additional characteristics that were tested but not significant in either of the models are Gender, Age, Educational level, Diagnosis during the acute Q-fever episode, BMI, Smoking behaviour and Hospitalisation, since they were not significantly associated with the selected subdomains in the multivariate analyses.

b) A lower score on the NCSI subdomains 'Fatigue' and 'General Quality of Life' indicates better health. A higher score on the SF-36 subdomain 'Role Physical' indicates better health.

c) For the subdomain 'Fatigue', also the characteristic Use of medication was statistically significant in the univariate analysis. In the multivariate model, it was removed via a backward analysis.

d) For the subdomain 'General Quality of Life', all characteristic that were statistically significant in the univariate analysis are included in the multivariate model.

e) For the subdomain 'Role Physical', also the characteristics Age and Use of medication were statistically significant in the univariate analysis. In the multivariate model, they were removed via a backward analysis.

f) Additional treatment for long-lasting health effects of Q-fever (e.g. fatigue). Treatments for Q-fever that are considered regular are Cognitive Behavioural Therapy, Graded Exercise Therapy, additional treatment with antibiotics or participation in the Qure study. ${ }^{31}$ Other treatments are considered non-regular. 